Article

\title{
Experimental Investigation, Techno-Economic Analysis and Environmental Impact of Bioethanol Production from Banana Stem
}

\author{
Nazia Hossain ${ }^{1, *(\mathbb{C})}$, Alyaa Nabihah Razali ${ }^{2}$, Teuku Meurah Indra Mahlia ${ }^{3}{ }^{\circ}$, \\ Tamal Chowdhury ${ }^{4}$, Hemal Chowdhury ${ }^{5} \mathbb{D}^{\text {, Hwai Chyuan Ong }}{ }^{3,6} \mathbb{C}^{\mathbb{B}}$, Abd Halim Shamsuddin ${ }^{2}$ \\ and Arridina Susan Silitonga ${ }^{7}$ \\ 1 Department of Civil and Infrastructure Engineering, School of Engineering, RMIT University, Melbourne, \\ VIC 3001, Australia \\ 2 Institute of Sustainable Energy, Universiti Tenaga Nasional, Selangor 43000, Malaysia; \\ undone57@gmail.com (A.N.R.); abdhalim@uniten.edu.my (A.H.S.) \\ 3 School of Information, Systems and Modeling, Faculty of Engineering and Information Technology, \\ University of Technology Sydney, Sydney, NSW 2007, Australia; TMIndra.Mahlia@uts.edu.au \\ 4 Department of Electrical and Electronic Engineering, Chittagong University of Engineering and Technology, \\ Chittagong 4349, Bangladesh; tamalshanto@gmail.com \\ 5 Department of Mechanical Engineering, Chittagong University of Engineering and Technology, \\ Chittagong 4349, Bangladesh; hemalchowdhuryme13@gmail.com \\ 6 Department of Mechanical Engineering, Faculty of Engineering, University of Malaya, Kuala Lumpur 50603, \\ Malaysia; onghc@um.edu.my \\ 7 Department of Mechanical Engineering, Politeknik Negeri Medan, Medan 20155, Indonesia; \\ ardinsu2301@gmail.com \\ * Correspondence: bristy808.nh@gmail.com; Tel.: +61-4-8012-3691
}

Received: 24 September 2019; Accepted: 14 October 2019; Published: 17 October 2019

\begin{abstract}
Banana stem is being considered as the second largest waste biomass in Malaysia. Therefore, the environmental challenge of managing this huge amount of biomass as well as converting the feedstock into value-added products has spurred the demand for diversified applications to be implemented as a realistic approach. In this study, banana stem waste was experimented for bioethanol generation via hydrolysis and fermentation methods with the presence of Saccharomyces cerevisiae (yeast) subsequently. Along with the experimental analysis, a realistic pilot scale application of electricity generation from the bioethanol has been designed by HOMER software to demonstrate techno-economic and environmental impact. During sulfuric acid and enzymatic hydrolysis, the highest glucose yield was 5.614 and $40.61 \mathrm{~g} / \mathrm{L}$, respectively. During fermentation, the maximum and minimum glucose yield was $62.23 \mathrm{~g} / \mathrm{L}$ at $12 \mathrm{~h}$ and $0.69 \mathrm{~g} / \mathrm{L}$ at $72 \mathrm{~h}$, respectively. Subsequently, $99.8 \%$ pure bioethanol was recovered by a distillation process. Plant modeling simulated operating costs $65,980 \mathrm{US} \$ / \mathrm{y}$, net production cost 869347 US $\$$ and electricity cost $0.392 \mathrm{US} \$ / \mathrm{kWh}$. The $\mathrm{CO}_{2}$ emission from bioethanol was $97,161 \mathrm{~kg} / \mathrm{y}$ and $\mathrm{SO}_{2}$ emission was $513 \mathrm{~kg} / \mathrm{y}$ which is much lower than diesel emission. The overall bioethanol production from banana stem and application of electricity generation presented the approach economically favorable and environmentally benign.
\end{abstract}

Keywords: acid hydrolysis; banana stem; bioethanol production; environmental analysis; enzymatic hydrolysis; HOMER software; techno-economics; yeast fermentation

\section{Introduction}

The adverse environmental impact, especially global warming due to excessive use of fossil fuel, has forced scientists to find alternative energy such as renewable energy. Many regions all over the 
world have emphasized solar energy due to the abundant sunlight in those regions [1,2]. However, the major limitation of solar and wind energy applications is that these sources of energy are merely available for a certain period of time [3]. Therefore, energy storage devices are required to store energy, such as batteries or other energy storage materials [4-6]. Besides that, many countries worldwide have highlighted biomass as an alternative fuel for renewable sources power generation $[7,8]$. Among south-east Asian regions, Indonesia, Thailand, Cambodia, Malaysia have successfully produced biodiesel from their tropical biodiversity sources [9-11]. Based on the previous experimental and statistical analyses, biomass could be turned into the Earth's most attractive alternative in the next decades since fossil fuel is depleting day by day. Lignocellulosic biomass is certainly considered as a new sustainable supply of combined glucose for fermentation to produce bioethanol as well as other biofuels and bio-products. Numerous technologies have been implemented in the last 50 years for effective biomass conversion to biofuels to augment biofuel as cost-competitive fuel in modern fuel market [12-16]. Bioethanol is deemed as one of the excellent energy resources that attribute for the spark-ignition internal combustion power plant. It contains higher octane and higher heat associated with vaporization, causes alcohol better to be a $100 \%$ pure energy resource than gasoline $[17,18]$. Hence, bioethanol is being implemented commercially in many chemical industries. A report conducted by Energy Efficiency and Renewable Energy, U.S. Department of Energy presented that ethylene and propylene can be manufactured from bioethanol, biopropanol, and biobutanol in the short term [19]. Production of polyethylene and polypropylene from this route has been commercialized in Braskem and a group of Dow Chemical and Crystalsev in Brazil [20].

Banana (Musa spp.) is one of the major harvested plants of numerous places around the world and the second-largest cultivated fruit in Malaysia. The tender core of the banana pseudo-stem is densely packed in the center (core) of the banana stem, tube-like shape with a diameter of approximately $5-6 \mathrm{~cm}$ [21]. This herbaceous banana plant is usually cultivated on 26,000 hectares of the total land of Malaysia and produces almost 530,000 metric ton of banana fruit per year. After each batch of mature banana fruit (usually 10-12 months), four times of banana waste (e.g., banana stem, leaves, fruit bunch, rotten fruit, and rhizomes) are abandoned to the environment [22,23]. After the banana collection, mostly the wastes are either left for natural degradation as fertilizer/soil conditioner for the purpose of nutrition and mulching or thrown to the barren land and that contributes to environmental pollution and troubles further replanting operations $[21,24,25]$. To accumulate this banana waste in an environment-friendly and cost-effective approach, bioethanol production concept has been introduced in this study. In addition, a previous study demonstrated that the banana stem is usually combined with cellulose $34.5 \%$, hemicelluloses $25.6 \%$, and low lignin $12 \%$ [26]. High cellulosic content with low lignin causes low resistance to enzymatic attack and makes banana stem a high potential lignocellulosic biomass which could be used for the production of bio-ethanol [27].

In the recent biofuel market, bioethanol is the most widespread and commercially produced biofuel. Mostly bioethanol is used for the transportation sector while it also can be potential for electricity generation and contribute to energy saving for the power sector. Diversified applications of bioethanol can boost the market value of bioethanol as well as encourage biofuel production industries to utilize biomass and waste biomass for higher conversion. This may have a major impact on both environmental and energy-saving aspects $[2,15,16,28]$. A study demonstrated that a solid-state fuel cell with electric motor and controller can produce electricity from bioethanol with 75-80\% conversion efficiency [29-31]. However, very little research and design have been conducted on bioethanol-electricity generation. To the author's best knowledge, no study has been performed on electricity generation from bioethanol produced from waste biomass so far. This study attempted primarily to manage banana stem waste of Malaysia for green fuel, bioethanol production and initiate a new addition, electricity from bioethanol to power sector by designing a plant scale through a diesel generator for a small town in Malaysia.

On the other hand, a higher amount of greenhouse gases, such as $\mathrm{CO}_{2}$, in Malaysia's environment appears as another crucial issue nowadays [32]. In 2008, based on high $\mathrm{CO}_{2}$ emission, Malaysia was 
ranked 26th among 149 countries worldwide and the excessive fossil fuel usage for electricity generation and transportation was the core reason behind it. To get rid of this increasing $\mathrm{CO}_{2}$ content from the environment, Malaysia started to emphasize renewable energies from several years earlier [33]. Besides $\mathrm{CO}_{2}$ pollution, there are additional pollutants such as soot, particulate matter (PM), nitrogen oxides (NOx) and others inside the exhaust gas mixture of the internal combustion engines. These pollutants emitted from conventional diesel engines also contribute significantly to air pollution [34]. The two major advantages for bioethanol applications in diesel engines are: (i) Bioethanol emits less $\mathrm{CO}_{2}$, Nox, and PM, (ii) bioethanol can be converted to hydrogen by using steam reforming system via waste utilization from heat recovery system and this hydrogen would improve the fuel combustion efficiency in the internal combustion engines [35]. Therefore, the Ministry of Plantation Industries and Commodities of Malaysia made a policy for bioenergy and biofuels for transport [36]. However, all research on bioenergy applications is mostly confined to transportation fuel and not much biofuel studies have been performed to play a significant role in electricity generation. Hence, no biofuel policy has been made in the power sector. Therefore, this study projects to contribute to the power sector with renewable biofuel.

The main objectives of this study are (i) to maximize glucose production from the banana stem, (ii) to investigate the potential of bioethanol production from the banana stem, (iii) to demonstrate the techno-economic and environmental analysis of experiments bioethanol-electricity supply through a diesel generator. This study demonstrates the maximum glucose with two delignification approaches: Acid hydrolysis by diluting sulfuric acid and enzymatic hydrolysis by cellulase enzymes. Later, yeast (Saccharomyces cerevisiae) fermentation was conducted to determine the maximum bioethanolic yield. Apart from the experimental investigation, a techno-economic and environmental optimization were performed by the HOMER software (The Micropower Optimization Model, Homer Energy for LLC, version 2.68 beta released by 24 July 2009) to project this experimented bioethanol converting into electricity generation by a diesel generator.

\section{Materials and Methods}

A technical flowsheet of banana stem-bioethanol-electricity supply has been presented in Figure 1. This flowchart presents the raw material (banana stem) transportation to bioethanol plant, pre-treatment of materials, handling processes (hydrolysis and fermentation), separation of pure product (bioethanol) and other by-products, as well as pure product conversion to end product and end product supply to consumers. 


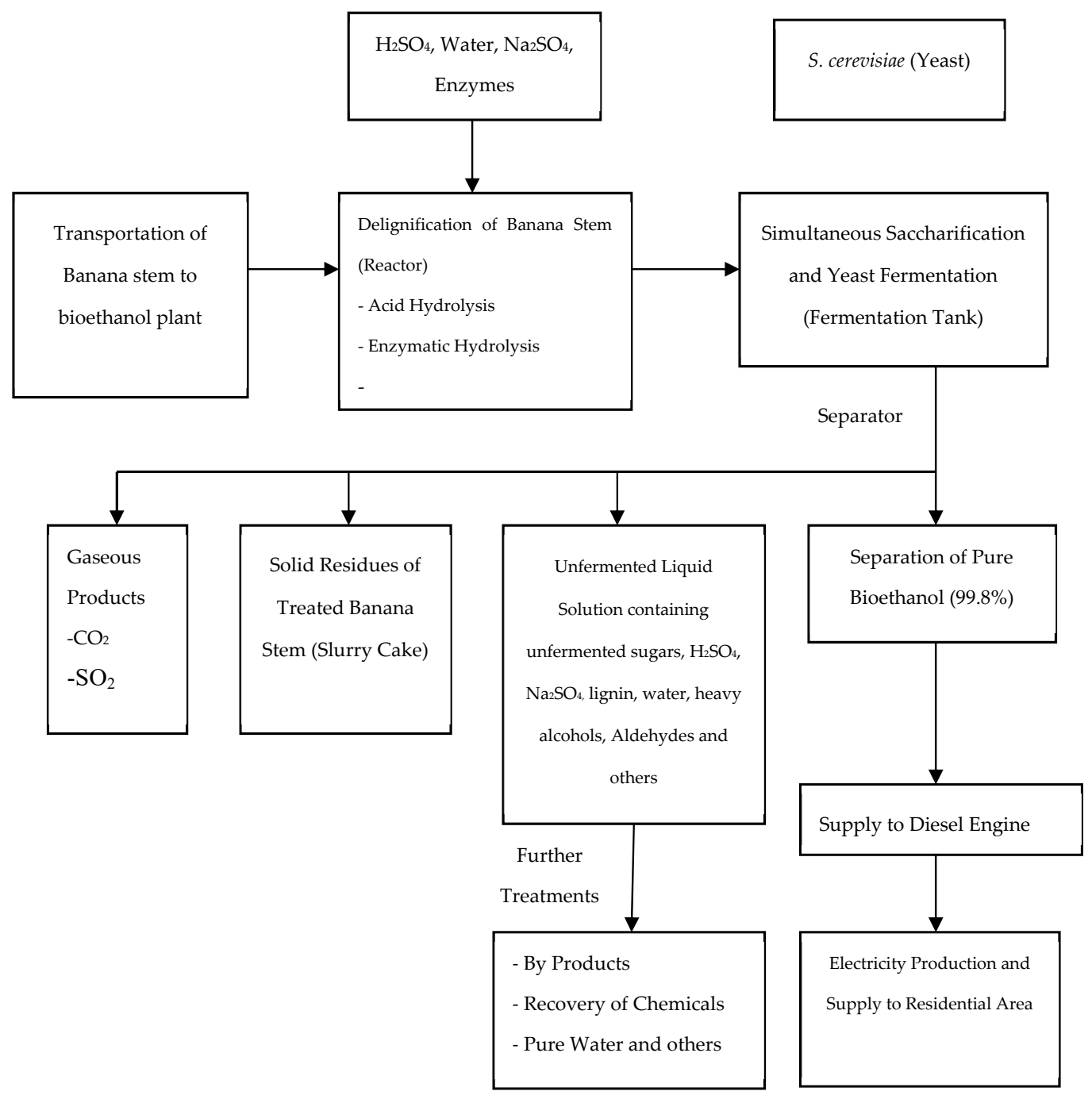

Figure 1. Technical flowsheet of banana stem-bioethanol-electricity supply.

\subsection{Collection and Preparation of Banana Stem}

A large amount of banana stem was collected locally and cut into small pieces. The stem pieces were ground by a top bench blending machine to trigger the reaction between a material and enzymes for further experiments. Figure 2 presents the collected banana stem for this experimental study. The ground banana stem was preserved in the chiller of $-3{ }^{\circ} \mathrm{C}$ to maintain and prevent the banana stem from rotting.
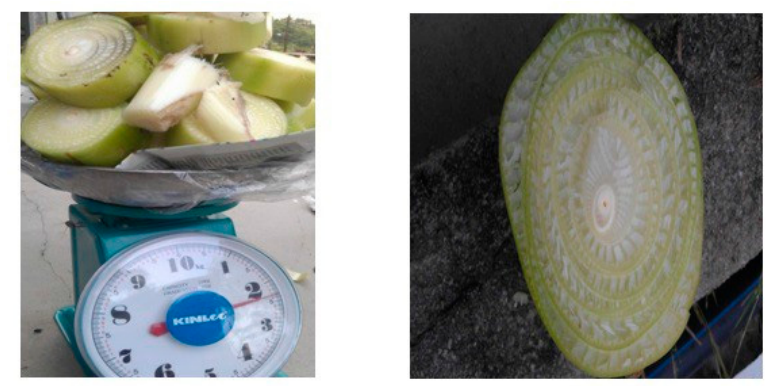

Figure 2. Collected banana stem. 


\subsection{Microorganism and Media Preparation}

Saccharomyces cerevisiae (yeast) was collected from the local market and used for metabolizing glucose to bioethanol under anaerobic conditions. Ten grams of potato dextrose agar (PDA) was dissolved in $250 \mathrm{~mL}$ distilled water to prepare the media. Then, the media was poured into bottles, test tubes, and flasks separately. The culture was inoculated by wetting the cotton swab in the media, dipping in the yeast packet and swirling it into the media again. Five grams of Saccharomyces cerevisiae was then introduced into the Petri dishes with the aid of a sterilized inoculating loop. A wad of cotton was placed on the top of each tube to prevent contamination. The yeast-containing Petri dish was incubated in a warm place with $35^{\circ} \mathrm{C}$ for $48 \mathrm{~h}$.

\subsection{Pre-Treatment of Banana Stem}

Two types of pre-treatment methods were performed in this study to separate the components of banana stem biomass (hemicelluloses, cellulose, and lignin) and make the remaining solid biomass easy to access for further chemical treatment.

\subsubsection{Acid Hydrolysis}

Sulfuric acid $\left(\mathrm{H}_{2} \mathrm{SO}_{4}, 0.5 \mathrm{M}\right)$ was prepared for the acid hydrolysis pre-treatment. Twenty grams of the ground banana stem was transferred into a flask with $0.5 \mathrm{M} \mathrm{H}_{2} \mathrm{SO}_{4}$. The media-containing flasks were inserted into a hot water bath for $90 \mathrm{~min}$ at $90{ }^{\circ} \mathrm{C}$ to ensure maximum possible reaction between the solid materials and acid solution at a temperature and reaction period. After cooling the hot media, $1 \mathrm{M}$ of sodium hydroxide $(\mathrm{NaOH})$ was dissolved in the flask to neutralize the media for maintaining media $\mathrm{pH}$ 4.0-6.0. Reaction 1 presented the neutralization process.

$$
\mathrm{H}_{2} \mathrm{SO}_{4}+2 \mathrm{NaOH} \rightarrow \mathrm{Na}_{2} \mathrm{SO}_{4}+2 \mathrm{H}_{2} \mathrm{O} \text { (Rc. 1) }
$$

After neutralizing the media, solution and solid materials were separated through filter paper. The clear liquid solution was obtained and preserved in the chiller. The solid material was rinsed with distilled water and dried in Memmert oven at $60^{\circ} \mathrm{C}$ for $24 \mathrm{~h}$ to evaporate all moisture.

\subsubsection{Enzymatic Hydrolysis}

Next, $1.3 \mathrm{~g}$ of oven-dried banana stem was dissolved in $100 \mathrm{~mL}$ sodium acetate $\left(\mathrm{CH}_{3} \mathrm{COONa}\right)$ solution ( $0.68 \mathrm{~g}$ solid $\mathrm{CH}_{3} \mathrm{COONa}$ ) into a flask for enzymatic hydrolysis. $1.0 \mathrm{M} \mathrm{NaOH}$ and $1.0 \mathrm{M}$ $\mathrm{H}_{2} \mathrm{SO} 4$ were added to adjust the $\mathrm{pH}$ between 4.0 to 6.0. Five grams of the purchase cellulose enzyme was added into the solution, and the flask was covered with cotton and aluminum foil. The flask was placed in the incubator shaker at $37^{\circ} \mathrm{C}, 150 \mathrm{rpm}$ for $48-72 \mathrm{~h}$. In the interval time of $12-24 \mathrm{~h}$, the samples were taken for the glucose test. After $72 \mathrm{~h}$, the samples were removed from incubator shaker, solid and solution of the flask was separated by a filter paper. The solution was preserved in a chiller for further experiments.

\subsection{Yeast Fermentation of treated Banana Stem}

S. cerevisiae was cultured earlier to perform the fermentation process and metabolize glucose to bioethanol. For this study, the fermentation process was carried out for $72 \mathrm{~h}$ continuously, confirming maximum yeast growth by consuming glucose containing the solution. All equipment was sterilized in an autoclave at $121{ }^{\circ} \mathrm{C}$ for $15 \mathrm{~min}$. A yeast solution combined of $10 \mathrm{~g}$ cultured yeast extract, $4 \mathrm{~g}$ potassium hydrogen phosphate $\left(\mathrm{KH}_{2} \mathrm{PO}_{4}\right), 2 \mathrm{~g}$ ammonium chloride $\left(\mathrm{NH}_{4} \mathrm{Cl}_{2}\right)$ and $1 \mathrm{~L}$ reverse osmosis (RO) water was prepared. Then, the preserved glucose solution after acid hydrolysis and enzymatic hydrolysis were combined for the fermentation process and sterilized at $121^{\circ} \mathrm{C}$ for $15 \mathrm{~min}$. Fifty $\mathrm{mL}$ of glucose solution was transferred into three flasks separately to run triplicates. The yeast solution was added into the glucose solution to each flask. Flasks were air-tightly closed with cotton and aluminum foil to maintain anaerobic conditions. Flasks were placed inside the incubator shaker at 37 
${ }^{\circ} \mathrm{C}$ and $150 \mathrm{rpm}$ for $72 \mathrm{~h}$. Fermentation temperature was set at $37^{\circ} \mathrm{C}$ since this temperature was very much favorable to enhance cellulase activity during enzymatic hydrolysis as well as fermentation in a previous study [37]. The samples were tested to determine glucose concentration at an interval time for every $12 \mathrm{~h}$.

\subsection{Glucose Determination}

Samples of glucose solution were taken into an Eppendorf tube, centrifuged by laboratory benchtop centrifuge machine at 10,000 rpm for $5 \mathrm{~min}$ for complete separation of the solid and liquid phase. One $\mathrm{mL}$ of upper liquid was transferred into a $50 \mathrm{~mL}$ centrifuge tube and $49 \mathrm{~mL}$ distilled water poured into the tube for dilution purpose. The tube was shaken well to mix the solution thoroughly. The $2 \mathrm{~mL}$ solution for each tube was transferred to several test tubes further. Two $\mathrm{mL}$ of 3 , 5-dinitrosalicylic acid (DNS) reagent was added to glucose analysis. All test tubes were covered with paraffin and immersed in a water bath at $90^{\circ} \mathrm{C}$ for $5 \mathrm{~min}$. Then, the observance of the samples was obtained by the laboratory UV spectrophotometer with a wavelength of $540 \mathrm{~nm}$.

Glucose Yield Analysis

Diluted sulfuric acid $\left(\mathrm{H}_{2} \mathrm{SO}_{4}\right)$ acid pre-treatment was applied due to method simplicity and low cost for primary depolymerization of the banana stem. Along with that, this treatment does not require high-tech and sophisticated equipment [26]. In previous studies, acid treatment was more effective than alkali hydrolysis on banana stem delignification [37]. This experiment was performed by using DNS reagent and the reading was obtained from the spectrophotometer at a wavelength of $540 \mathrm{~nm}$. The molarity of $\mathrm{H}_{2} \mathrm{SO}_{4}$ was $0.5,1.0,1.5$, and $2.0 \mathrm{M}$. The hydrolysis period taken for this treatment was $60 \mathrm{~min}$ and $90 \mathrm{~min}$.

\subsection{Biomass Production}

For biomass production analysis, the solid phase left in the lower part of the Eppendorf tube was analyzed. One $\mathrm{mL}$ of reverse osmosis $(\mathrm{RO})$ water was transferred into the Eppendorf tube. The solid phase with RO water was mixed thoroughly by a vortex. Then, the observance of the samples was obtained by the laboratory UV spectrophotometer with a wavelength of $640 \mathrm{~nm}$. Distilled water was used as the reference reading.

\subsection{Bioethanol Recovery by Distillation}

The distillation process was applied in this study to purify bioethanol from fermented solutions. For bioethanol distillation, the heating temperature was set to be between $65^{\circ} \mathrm{C}$ and $75^{\circ} \mathrm{C}$ in a rotary evaporator for bioethanol distillation. One hundred $\mathrm{mL}$ of the fermented solution was transferred into the rotary evaporator flask, this flask was attached to the distillation chamber and immersed in a hot water bath to evaporate the gas. The vacuum temperature was set at $0.8 \mathrm{kPa}$ and the speed controller was at one. The distillation process was run with $40 \mathrm{~min}$ under vacuum conditions. After the distillation process, pure bioethanol (99.8\%) was collected and measured by a measuring cylinder.

\subsection{Techno-Economics and Environmental Analysis}

A pilot-scale economic analysis was performed to determine the energy savings by bioethanol from the banana stem application. A pilot-scale bioethanol plant has been projected to set up in a small city in Malaysia, which contains three types of residents: Low, medium, and high-income residents. Average energy loads for different types of residents have been identified. The economic and environmental optimization of this study was simulated by HOMER Software based on the load profile for each hour of the day. HOMER software usually optimizes micro-power models and designs power systems with numerous applications in both off-grid and on-grid [38]. Along with model optimization, this software provided the economic cost estimation and gas emissions. 


\subsubsection{Diesel Generator}

The diesel generator considered in the present study was for power $(\mathrm{kW})$ generation and it was fueled by diesel. The fuel consumption rate $\left(\mathrm{m}^{3}\right)$ of a diesel generator to generate electricity was simulated by Equation (1).

$$
L=L_{0, d g} Y_{d g}+L_{1, d g} P_{d g}
$$

where, $L_{0}$ : Fuel curve intercept coefficient $\left(0.000205 \mathrm{~m}^{3} / \mathrm{h}\right), L_{1}$ : Fuel curve slope $\left(0.00025 \mathrm{~m}^{3} / \mathrm{h} / \mathrm{kW}\right)$, $Y_{d g}:$ Rated capacity of the generator $(\mathrm{kW}), P_{d g}$ : Electrical output of the generator $(\mathrm{kW})$.

\subsubsection{Economic Analysis}

Economic analysis was performed by Homer software. Homer concluded the optimum result based on the cost of energy, COE $(\$ / \mathrm{kWh})$, and net present cost (NPC). COE was determined by Equation (2).

$$
C O E=\frac{C_{A}}{E_{S}}
$$

where, $C_{A}$ (\$/year) depicts the sum of every year capital, replacement, and operational and maintenance cost of each component and $E_{S}(\mathrm{kWh})$ is the energy generated in a year to meet the demand $(\mathrm{kW} / \mathrm{y})$ [1].

The net present cost, $C_{N P C}(\$)$ was the ratio of total annual cost $\left(C_{A}\right)$ to capital recovery factor $(C R F)$ and evaluated by Equations (3)-(5).

$$
\begin{aligned}
C_{N P C} & =\frac{C_{A}}{\operatorname{CRF}(i, N)} \\
\operatorname{CRF}(i, N) & =\frac{i(1+i)^{N}}{(1+i)^{N}-1} \\
i & =\frac{i \prime-f}{1+f}
\end{aligned}
$$

where, $i$ is the annual real interest rate (\%), $i$ r represents nominal interest rate $(\%), f$ denotes annual inflation rate (\%), and $N$ is the project lifetime. In this study, the annual inflation rate considered is $2 \%$, whereas the annual interest rate considered is $8 \%$.

\subsubsection{Environmental Analysis:}

In this study, life cycle emission, $\operatorname{LCE}\left(\mathrm{kg} \mathrm{CO}_{2}-\mathrm{eq} / \mathrm{yr}\right)$ has been performed to determine the quantity of equivalent $\mathrm{CO}_{2}$ and $\mathrm{SO}_{2}$ emission from the energy used to transport, manufacture and recycle the components used to model the system. The mathematical expression of Equation (6) has been used to calculate life cycle emission [39].

$$
L C E=\sum_{i=1}^{x} B_{i} E_{L}
$$

where $x$ depicts the number of components used to model the system, $E_{L}(\mathrm{kWh})$ represents the energy generated and reserved in each units or components, $B_{i}\left(\mathrm{~kg} \mathrm{CO}_{2}-\mathrm{eq} / \mathrm{kWh}\right)$ and $B_{i}\left(\mathrm{~kg} \mathrm{SO}_{2}-\mathrm{eq} / \mathrm{kWh}\right)$ denote the lifetime equivalent $\mathrm{CO}_{2}$ and $\mathrm{SO}_{2}$ emissions of various components to model the system, respectively. In this study for diesel generator, the values considered are $0.88 \mathrm{~kg} \mathrm{CO}_{2}$-eq/ $\mathrm{kWh}$ and $0.000002 \mathrm{~kg} \mathrm{SO}$-eq $/ \mathrm{kWh}[39,40]$. In Homer, all of the technical and economical parameters are input to simulate the system.

\section{Results and Discussions}

The banana stem was prefered as raw material for bioethanol production due to the significant amount of intracellular lignocellulosic content [26]. A bioethanolic study on banana stem presented $44.6 \%$ cellulose, $36 \%$ hemicelluloses, and $19.4 \%$ lignin in the banana stem [37]. A large amount of 
cellulose and hemicellulose content can be converted into bioethanol through a fermentation process where lignin is a barrier for complete conversion. Lignin contains the complex cellular structure and is resistant to the activity of many microbes and chemical reagents [37]. Raw banana stems delignification processes: Acid hydrolysis and enzymatic hydrolysis before fermentation was carried out to degrade the lignocelluloses, especially lignin, in this study. Alkali pre-treatment can remove lignin effectively, but this treatment leaves the remaining carbohydrates quite intact. Since carbohydrate degradation is the main purpose of this, alkali pre-treatment was not run as delignification approach for the banana stem. Other effective delignification processes, like wet oxidation, solvent and metal complexes, steam explosion, liquid hot water, ammonia fiber expansion, supercritical fluid treatment and thermochemical treatment, were not applied due to higher raw material processing cost [20,21].

\subsection{Glucose Yield Analysis during Pre-Treatment}

The obtained glucose concentration results were tabulated in Table 1. From Table 1, the maximum glucose yield by acid hydrolysis was obtained as $5.61 \mathrm{~g} / \mathrm{L}$, the optimum time and $\mathrm{H}_{2} \mathrm{SO}_{4}$ concentration for the highest yield were determined as $90 \mathrm{~min}$ of acid hydrolysis and $0.5 \mathrm{M} \mathrm{H}_{2} \mathrm{SO}_{4}$, respectively. This result showed that the banana stem reacted with $\mathrm{H}_{2} \mathrm{SO}_{4}$ and treated perfectly during this optimum time and molarity. Therefore, a similar parameter was projected to apply for further processes to obtain the highest bioethanolic yield. For 1.0, 1.5, and $2.0 \mathrm{M}_{\text {of }} \mathrm{H}_{2} \mathrm{SO}_{4}$, the results of Table 1 manifested that glucose yields were higher at $60 \mathrm{~min}$ hydrolysis period compared to 90 min hydrolysis period.

Table 1. Glucose yield during acid hydrolysis.

\begin{tabular}{cccc}
\hline H2SO4 Concentration (Molar) & Time (min) & Optical Density (OD) & Glucose Yield (g/L) \\
\hline \multirow{2}{*}{0.5} & 60 & 0.006 & 0.717 \\
& 90 & 0.047 & 5.614 \\
\hline \multirow{2}{*}{1.0} & 60 & 0.013 & 1.553 \\
& 90 & 0.008 & 0.956 \\
\hline \multirow{2}{*}{1.5} & 60 & 0.007 & 0.836 \\
& 90 & 0.006 & 0.717 \\
\hline \multirow{2}{*}{2.0} & 60 & 0.031 & 3.703 \\
& 90 & 0.001 & 0.119 \\
\hline
\end{tabular}

The second pre-treatment of the banana stem was enzymatic hydrolysis and the pre-treatment was conducted by using DNS reagent and reading was obtained at a wavelength of $540 \mathrm{~nm}$. The results are presented in Table 2.

Table 2. Glucose yield during enzymatic hydrolysis.

\begin{tabular}{ccc}
\hline Time (h) & Optical Density (OD) & Glucose Yield (g/L) \\
\hline 24 & 0.226 & 26.99 \\
48 & 0.266 & 31.77 \\
72 & 0.340 & 40.61 \\
\hline
\end{tabular}

For the enzymatic hydrolysis, the time interval for the experimental sample was at $24 \mathrm{~h}, 48 \mathrm{~h}$, and $72 \mathrm{~h}$. DNS test through optical density was carried out for each time interval to analyze the samples. Based on Table 2, OD was positively correlated with a time interval. The highest glucose yield, $40.61 \mathrm{~g} / \mathrm{L}$ was achieved at $72 \mathrm{~h}$ of enzymatic reactions. This result manifested that the cellulase enzyme was very active and reacted maximum with the sodium acetate and dried banana stem with the time increase. The previous study on enzymatic hydrolysis of banana stem presented maximum saccharification at $48 \mathrm{~h}$ [21]. The current study unveiled that $24 \mathrm{~h}$ additional hydrolysis enhanced glucose yield, $8.84 \mathrm{~g} / \mathrm{L}$ more compared to $48 \mathrm{~h}$ hydrolysis. Apart from that, this study determined 
the highest amount of glucose content among all the previous studies done for the banana stem in other countries, such as Taiwan, Brazil, India, and Indonesia [21,26,37,41]. Applications of efficient catalysts and nano-catalysts may enhance the effectiveness of cellulase enzyme and lead to a higher rate of delignification. One study suggested that solid nano-particles and nano-droplets application as an immobilized bed of expensive enzymes could break down the long chain of complex sugar continuously with a faster rate and produce more simple sugar, which drives a few times higher bioethanol production [42]. Hence, highly efficient enzymes and nanocatalysts will be implemented in further experiments.

\subsection{Glucose and Biomass Content Analysis during Fermentation Process}

For every $12 \mathrm{~h}$ time interval, the samples were taken out and chilled inside the chiller before analyzing the process. The determination of optical density was done by using DNS reagent and the reading was obtained from the spectrophotometer at a wavelength of $540 \mathrm{~nm}$. The obtained results have been shown in Table 3.

Table 3. Glucose and biomass content analysis during fermentation.

\begin{tabular}{cccc}
\hline Time (h) & Optical Density (OD) & Glucose Yield (g/L) & Biomass Content Yield (g/g) \\
\hline 12 & 0.521 & 62.23 & 0.006 \\
24 & 0.007 & 0.83 & 0.139 \\
36 & 0.020 & 2.39 & 0.135 \\
48 & 0.035 & 4.18 & 0.133 \\
60 & 0.052 & 6.21 & 0.212 \\
72 & 0.008 & 0.69 & 0.462 \\
\hline
\end{tabular}

From the tabulated data of Table 3, the highest glucose yield, $62.23 \mathrm{~g} / \mathrm{L}$ was obtained in $12 \mathrm{~h}$ fermentation period. For each experiment, triplicates have been conducted and the average value was considered. The value of glucose yield reached a peak at the interval time of $12 \mathrm{~h}$. At $24 \mathrm{~h}$ of fermentation time, the glucose content decreased tremendously and in other time interval presented comparatively lower glucose content than $12 \mathrm{~h}$ time interval. It can be concluded that $S$. cerevisiae still has not consumed a large amount of glucose content inside the solution. A previous saccharification study from oil palm trunk (OPT) demonstrated that Epsom salt $\left(\mathrm{MgSO}_{4}\right)$ and alanine amino acid $\left(\mathrm{C}_{3} \mathrm{H}_{5} \mathrm{NO}_{2}\right)$ addition, during hydrolysis increased the sugar yield from $12.52 \%$ to $17.19 \%$ [27]. Hence, additional supplements, such as vitamin $B_{12}$, Epsom salt, alanine amino acid, and other vitamins-minerals, as well as recombinant yeast and yeast strains to the fermentation solution, are highly recommended for further experiments to obtain desired sugar content [43].

The biomass content analysis was not involved with the DNS test. The sediment at the bottom of Eppendorf tube was mixed with RO water and went through the vortex process. While the process was conducted, OD was analyzed by the spectrophotometer and biomass content yield was determined. Table 3 presented the biomass content yield during fermentation. Besides glucose yield, Table 3 also revealed that the biomass content yield increased with fermentation period and increased significantly once fermentation reached $72 \mathrm{~h}$, which was the maximum biomass content yield. This biomass content manifested that the $S$. cerevisiae produced the end-product called a waste product. This biomass was produced from the reaction between S. cerevisiae and the glucose content inside the solution during the fermentation process. This biomass content output maintained an output consistency of the previous study where banana stems biomass content was obtained $0.104 \mathrm{~g} / \mathrm{g}$ at $12 \mathrm{~h}$ and $0.201 \mathrm{~g} / \mathrm{g}$ at $72 \mathrm{~h}$ after yeast fermentation of banana stem [21]. An experimental study on bioethanol production in the wine industry showed that assimilable nitrogen deficiency in the growth media is the most prevalent cause of high biomass content within days to weeks, which is considered as sluggish formation. The intracellular analysis of this study also presented trehalose accumulation, which is 
directly correlated with bioethanol production and could be responsible for sustaining cell viability in nitrogen-poor musts independent of the initial assimilable nitrogen content [44].

\subsection{Pure Bioethanol after Distillation}

The last stage to achieve the final product was pure bioethanol recovery by the distillation process. After the fermentation process, the distillation process for the fermentation solution was carried out in triplicates. The pure bioethanol was recovered after $30-40 \mathrm{~min}$ of the distillation process. The average result obtained from the distillation process was demonstrated in Table 4 . Table 4 shows that the pure bioethanolic yield was $0.25 \mathrm{~mL} / \mathrm{mL}$ fermented solution or $25 \%$. After obtaining distilled bioethanol, the left-over solution may contain unfermented sugars, by-products (heavy alcohols, aldehydes, and others), $\mathrm{Na}_{2} \mathrm{SO}_{4}$, water, lignin, and gaseous components: $\mathrm{CO}_{2}$ and $\mathrm{CH}_{4}[27,45]$. The bioethanol of banana stem grown in Malaysia was higher than the highest leading feedstock for bioethanol of the country, oil palm trunk (OPT). The experimental study of bioethanol from OPT presented 33.5\% bioethanol after $72 \mathrm{~h}$ of fermentation, which is $8.5 \%$ higher than the banana stem.

Table 4. Pure bioethanol by the distillation process.

\begin{tabular}{cc}
\hline Items & Unit \\
\hline Distilled bioethanol $(\mathrm{mL})$ & 25 \\
Total fermented solution $(\mathrm{mL})$ & 100 \\
Bioethanolic yield (mL bioethanol/mL fermented solution) & 0.25 or $25 \%$ \\
\hline
\end{tabular}

Along with a usual bioethanol yield of OPT, that study also revealed the nutrient addition: Epsom salt $\left(\mathrm{MgSO}_{4}\right)$ and alanine amino acid $\left(\mathrm{C}_{3} \mathrm{H}_{5} \mathrm{NO}_{2}\right)$ in the fermentation solution boosted the bioethanol output from $33.5 \%$ to $48.28 \%$ at $72 \mathrm{~h}$ of OPT sap fermentation [43]. Therefore, suitable supplement addition during fermentation is strongly recommended for maximum bioethanolic yield from the banana stem in the future. In addition, recombinant yeast and yeast strains such as recombinant $S$. cerevisiae $(0.91 \mathrm{~g} / \mathrm{L}$ bioethanolic yield), recombinant S. pombe $(0.42 \mathrm{~g} / \mathrm{L})$, C. shehatae CBS $4705(0.48 \mathrm{~g} / \mathrm{L})$, P. stipitis CBS $5776(0.45 \mathrm{~g} / \mathrm{L})$ will also be applied as a fermentation tool instead of $S$. cerevisiae in further experiments to improve the bioethanol output. Another future plan to boost bioethanol productivity for the banana stem is to co-culture other yeasts, e.g., Candida guillermondii, Candida tropicalis during fermentation to degrade the pentoses (sugar content) and converted into value-added co-product and alternative sweetener, xylitol [17,46,47].

\subsection{Techno-Economics and Environmental Analysis}

Pilot-scale economic analysis determined energy savings through obtained bioethanol application and electricity generation from bioethanol in the Gombak region, Malaysia. The electricity produced from bioethanol was planned to be distributed among Gombak residents. At first, power rating data of different loads of a typical Malaysian household were collected. Then, the collected data were multiplied by numbers of loads connected and their operating hours to get the connected load. Average energy loads for different types of residents are presented in Table 5. Figure 3 shows daily load profiles for each hour of the day.

Table 5. Average energy load of different types of residents living in the projected arena.

\begin{tabular}{cccccccc}
\hline Load & $\begin{array}{c}\text { Power Rating } \\
\text { (W) }\end{array}$ & $\begin{array}{c}\text { Low-Income } \\
\text { Household }\end{array}$ & $\begin{array}{c}\text { Medium Income } \\
\text { Household }\end{array}$ & \multicolumn{2}{c}{$\begin{array}{c}\text { High-Income } \\
\text { Household }\end{array}$} \\
\cline { 3 - 8 } & & No of Items & h/Day & No of Items & h/Day & No of Items & h/Day \\
\hline Energy Efficient bulb & 20 & 3 & 4 & 4 & 5 & 5 & 6 \\
Mobile Charger & 25 & 1 & 3 & 3 & 2 & 4 & 2 \\
Fan & 70 & 1 & 4 & 2 & 7 & 3 & 8 \\
TV & 80 & & & 1 & 6 & 1 & 6 \\
Fridge & 150 & & & & & 1 & 24 \\
\hline
\end{tabular}




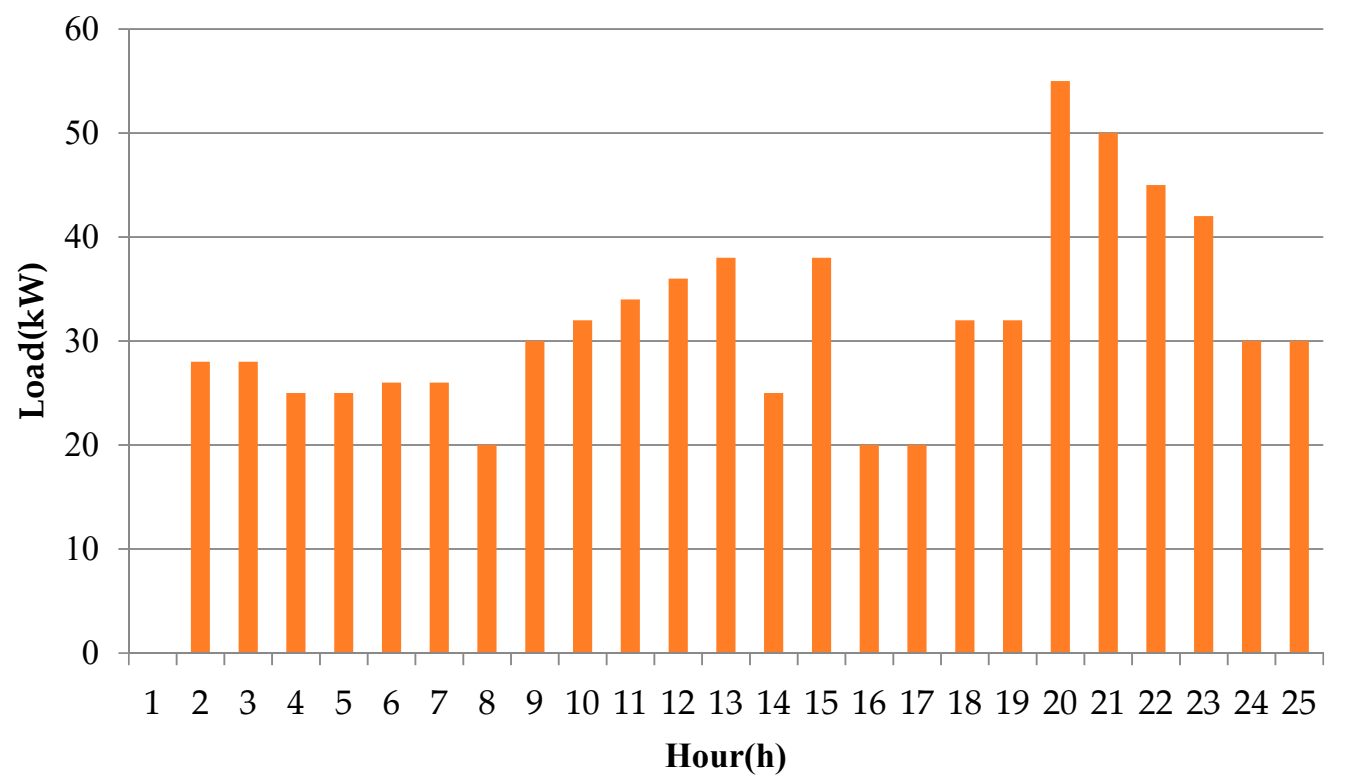

Figure 3. Daily load profile for each hour of the day.

The fuel properties of diesel and bioethanol are presented in Table 6. These parameters were input in the Homer software to operate the diesel generator. In this study, the fuel properties of diesel and desired bioethanol density were applied by the Homer software database. The total pure bioethanol yield from the experimented banana stem was $25 \%$. The banana stem contains heating value $15.4 \mathrm{MJ} / \mathrm{kg}$, carbon content $37.7 \%$ and sulfur content $0.37 \%$ [22]. During the techno-economic simulation, bioethanol fuel application was analyzed and compared with diesel since diesel is the dominant fuel in a diesel generator. Bioethanol is recommended in this study to be initially blended with diesel [48-50]. Table 9 depicts the techno-economic parameters for simulation of diesel generator by Homer software. Table 7 demonstrates that the cost of electricity produced by bioethanol was less than the dominant fossil fuel diesel. Besides that, the operating cost and the production cost of electricity from bioethanol was much lower compared to diesel fuel. One of the limitations of simulation of the operating cost is that this simulating approach did not consider the possibility of the corrosion of the chemical installation's metallic components. Due to the presence of bioethanol, ethanol-gasoline blends (EGBs) can easily absorb large amounts of water which may result in corrosion. Moreover, acidic compounds and ions can be dissolved in water and these substances can have corrosive effects on metallic construction materials [51].

Table 6. Fuel properties of diesel and bioethanol.

\begin{tabular}{ccc}
\hline Parameters & Diesel & Bioethanol \\
\hline Lower heating value $(\mathrm{MJ} / \mathrm{kg})$ & 43.2 & $15.4[22]$ \\
Density $\left(\mathrm{kg} / \mathrm{m}^{3}\right)$ & 820 & 820 \\
Carbon $(\mathrm{C})$ content $(\%)$ & 88 & $37.7[22]$ \\
Sulfur $(\mathrm{S})$ content $(\%)$ & 0.33 & $0.37[22]$ \\
\hline
\end{tabular}

Table 7. Economical parameters after result simulation for the proposed case.

\begin{tabular}{ccc}
\hline Economical Parameters & Diesel & Bioethanol \\
\hline Initial Capital $(\$)$ & 25,900 & 25,900 \\
Operating Cost $(\$ / y)$ & 77,235 & 65,980 \\
Net Production Cost $(\$)$ & $1,013,217$ & 86,9347 \\
Cost of electricity $(\$ / \mathrm{kWh})$ & 0.457 & 0.392 \\
\hline
\end{tabular}


Apart from the techno-economic simulation, the environmental effect of bioethanol utilization has been simulated by this study. Table 8 reveals that while bioethanol was used as fuel, almost 2.5 times environmental pollution by $\mathrm{CO}_{2}$ has been turned down compared to diesel utilization. Reducing $\mathrm{CO}_{2}$ in the environment has become an emerging issue all over the world, including Malaysia [52-54]. Another fact is that the banana stem absorbs $\mathrm{CO}_{2}$ from the environment for growth purposes since it is a renewable energy source, while diesel purely adds $\mathrm{CO}_{2}$ to the environment without any absorption. For $\mathrm{SO}_{2}$ emission, diesel and bioethanol produced $\mathrm{SO}_{2}$ almost in a similar range.

Table 8. Emission comparison between fossil diesel and experimented bioethanol combustion.

\begin{tabular}{ccc}
\hline Greenhouse Gases & Diesel & Bioethanol \\
\hline $\mathrm{CO}_{2}(\mathrm{~kg} / \mathrm{y})$ & 227,975 & 97,161 \\
$\mathrm{SO}_{2}(\mathrm{~kg} / \mathrm{y})$ & 458 & 513 \\
\hline
\end{tabular}

Table 9. Techno-economic parameters considered for the simulation of diesel generator.

\begin{tabular}{cccccccc}
\hline Components & $\begin{array}{c}\text { Technical } \\
\text { Description }\end{array}$ & $\begin{array}{c}\text { Capital } \\
\text { Cost (\$) }\end{array}$ & $\begin{array}{c}\text { Replacement } \\
\text { Cost (\$) }\end{array}$ & $\begin{array}{c}\text { Operation and } \\
\text { Maintenance } \\
\text { Cost (\$) }\end{array}$ & $\begin{array}{c}\text { Lifetime } \\
\text { (y) }\end{array}$ & $\begin{array}{c}\text { Fuel Price of } \\
\text { (\$/L) Diesel }\end{array}$ & $\begin{array}{c}\text { Fuel Price of } \\
\text { (\$/L) } \\
\text { Bioethanol }\end{array}$ \\
\hline $\begin{array}{c}\text { Diesel } \\
\text { generator }\end{array}$ & $70 \mathrm{KW}$ & $370 / \mathrm{KW}$ & $296 / \mathrm{KW}$ & $0.050 / \mathrm{h}$ & $15,000 \mathrm{~h}$ & $0.53[55]$ & $0.40[56]$ \\
\hline
\end{tabular}

\subsection{Practical Implications and Policy}

To apply the design outcomes in a realistic approach in Gombak City, some merits and demerits can be outlined to set up this plant scale industry. The advantages can be:

$>$ Bioenergy production from biomass has been practiced in Malaysia for decades. Alternative fuel research is very popular and numerous grants from the government have been invested in Malaysia to encourage biofuel production and application. Therefore, an initiative to establish this bioethanol to power generation is projected to attract government fuel policy and there is a great possibility to get assistance from a local government fund.

$>$ Waste management and environmental pollution are a hot issue in Malaysia nowadays. Many types of research are being performed to utilize wastes and reduce greenhouse gases from the environment. Using banana stem waste for bioethanol can cover both waste management and cleaner production, which may attract the energy and environment sector of the country.

$>$ The core raw material, the banana stem can be obtained at a very cheap price in large amounts since Malaysia is the second-largest banana producer worldwide [21]. Therefore, for this case, raw material costs will be negligible. Since the banana stem has got a soft and juicy texture, extra chemicals will not be required for softening and delignification. Hence, the handling cost will be very low. Moreover, high pre-treatment and handling cost is the main reason for growing popularity of biofuel production from most of the hard biomass such as rice and wheat straw, husk, willow, seeds, and others [57]. Additionally, the 'National Biofuel Policy' of The Govt. of Malaysia (GOM), 2006 excluded bioethanol due to the advanced technology and high price of pre-treatment cost of palm oil mill effluent and the high price of raw material, sugarcane [58].

The challenges may appear as:

> Since banana stem cannot be obtained at a consistent amount all over the year, the production of a inconsistent amount of bioethanol and electricity is expected. In this case, other feedstocks for bioethanol (e.g., oil palm trunk, fronds, leaves) are recommended to be integrated since oil palm is the highest abandoned biomass in Malaysia [27].

$>$ There is an established Malaysian Government Renewable Energy Policy named 'Bioenergy, Biofuels for Transport' of policy type 'Regulatory Instruments, Policy Support and Strategic 
Planning' under The Ministry of Plantation Industries and Commodities, Malaysia which is based on transportation fuel. Therefore, this project needs to be elaborately analyzed further to attract the Malaysian Government Renewable Energy Policy [36]. This policy is subjected to contribute to individual industries, socio-economic and environmental progress by creating new employment opportunities lower educated to higher educated man-force.

$>$ This design is an initial attempt and was simulated based on HOMER software. To achieve realistic figures, more detailed techno-economic analysis containing maintenance and raw material cost, life-cycle cost, by-products sale, plant profit, sensitivity analysis of all related factors besides initial, operating, production cost and product selling price are needed to be considered for more precision and conciseness.

$>$ A comprehensive life cycle assessment containing land and water footprint, chemical usage and energy balance besides $\mathrm{CO}_{2}$ and $\mathrm{SO}_{2}$ determination will be needed for a realistic approach. We will continue extensive life cycle cost analysis and life cycle assessment in our future work.

\section{Conclusions}

Banana stem has been experimented for bioethanol production in India, Indonesia, Brazil and other countries previously. This study strived to present the initial bioethanol production from banana stem based on a laboratory scale for the scenario of Malaysia. Since banana stem is one of the largest bio-wastes in the country, this study emphasized the possible scale-up conditions and designed a pilot-scale bioethanol production scheme for commercial transportation fuel application. To the authors' best knowledge, this is the first initiative to implement bioethanol (obtained from the banana stem) for transportation fuel in mercantile approach within Malaysia. This project's outcomes can be deemed as a major contribution to the biofuel industry in Malaysia.

To summarize the experimental outcomes, diluted sulfuric acid $\left(\mathrm{H}_{2} \mathrm{SO}_{4}\right)$ and enzymatic hydrolysis have been shown to very effective pre-treatment approaches through adequate glucose production. The pre-treated solution was further processed for fermentation to metabolize obtained glucose into bioethanol by the presence of $S$. cerevisiae (yeast) at $37^{\circ} \mathrm{C}, 150 \mathrm{rpm}$ for $72 \mathrm{~h}$. The fermentation approach resulted in decreased glucose content, and gradually increased biomass content during the fermentation period. Techno-economic analysis of the electricity production from banana stem bioethanol presented low operating cost, net production cost, and electricity cost compared to the dominating fossil fuel, diesel fuel of the international fuel market. In addition, environmental analysis simulated $97,161 \mathrm{~kg} /$ year $\mathrm{CO}_{2}$ emission from this process which is 2.5 times less than the diesel emission and $513 \mathrm{~kg} /$ year $\mathrm{SO}_{2}$ which is a similar range with diesel emission. This study recommends producing bioethanol from wasted banana stem in mercantile approach and blending with diesel fuel to generate electricity what will be economically sound and environmentally benign.

This study presented the highest bioethanol amount from wasted banana stem among all the studies performed earlier. Besides the highest bioethanol content, this study initiated an applied design to generate electricity from this bioethanol, which is the prior novelty of this project. Beyond transportation fuel applications, this design presented a new window for diversification of bioethanol implications. That could be a new fuel outlook for the pilot and large-scale bioethanol production, which can accumulate waste biomass besides regular feedstock. Hence, it may be a significant contribution to waste management, reduction of greenhouse gases, and cleaner production.

Author Contributions: Conceptualization, N.H. and A.N.R.; methodology, A.N.R.; software, T.C., H.C.; validation, T.M.I.M., H.C.O., A.H.S. and A.S.S.; formal analysis, N.H.; investigation, N.H.; resources, A.N.R.; data curation, A.N.R.; writing-original draft preparation, N.H.; writing-review and editing, N.H.; visualization, N.H.; supervision, T.M.I.M; project administration, H.C.O., A.H.S. and A.S.S.; funding acquisition, T.M.I.M.

Funding: Sincere gratitude to the Ministry of Energy, Science, Technology, Environment, And Climate Change (MESTECC) for the financial support given under the AAIBE Chair for Renewable Energy (Grant No. 201801KETTHA) and the APC was funded by University of Technology Sydney. Authors would like to thank Direktorat Jenderal Penguatan Riset dan Pengembangan Kementerian Riset, Teknologi dan Pendidikan Tinggi Republik Indonesia, (Grant no. 147/SP2H/LT/DRPM/2019) and Politeknik Negeri Medan, Medan, Indonesia. 
Conflicts of Interest: The authors declare no conflict of interest. The funders had no role in the design of the study; in the collection, analyses, or interpretation of data; in the writing of the manuscript, or in the decision to publish the results.

\section{References}

1. Ismail, M.S.; Moghavvemi, M.; Mahlia, T.M.I. Techno-Economic Analysis of an Optimized Photovoltaic and Diesel Generator Hybrid Power System for Remote Houses in a Tropical Climate. Energy Convers. Manag. 2013, 69, 163-173. [CrossRef]

2. Hossain, N.; Mahlia, T.M.I. Progress in Physicochemical Parameters of Microalgae Cultivation for Biofuel Production. Crit. Rev. Biotechnol. 2019, 39, 835-859. [CrossRef] [PubMed]

3. Ismail, M.S.; Moghavvemi, M.; Mahlia, T.M.I. Characterization of PV Panel and Global Optimization of its Model Parameters Using Genetic Algorithm. Energy Convers. Manag. 2013, 73, 10-25. [CrossRef]

4. Amin, M.; Putra, N.; Kosasih, E.A.; Prawiro, E.; Luanto, R.A.; Mahlia, T. Thermal Properties of Beeswax/Graphene Phase Change Material as Energy Storage for Building Applications. Appl. Therm. Eng. 2017, 112, 273-280. [CrossRef]

5. Latibari, S.T.; Mehrali, M.; Mehrali, M.; Mahlia, T.M.I.; Metselaar, H.S.C. Synthesis, Characterization and Thermal Properties of Nanoencapsulated Phase Change Materials via Sol-Gel Method. Energy 2013, 61, 664-672. [CrossRef]

6. Mehrali, M.; Latibari, S.T.; Mehrali, M.; Mahlia, T.M.I.; Metselaar, H.S.C. Preparation and Properties of Highly Conductive Palmitic Acid/Graphene Oxide Composites as Thermal Energy Storage Materials. Energy 2013, 58, 628-634. [CrossRef]

7. Uddin, M.; Techato, K.; Taweekun, J.; Rahman, M.; Rasul, M.; Mahlia, T.; Ashrafur, S. An Overview of Recent Developments in Biomass Pyrolysis Technologies. Energies 2018, 11, 3115. [CrossRef]

8. Hossain, N.; Zaini, J.; Mahlia, T.; Azad, A.K. Elemental, Morphological and Thermal Analysis of Mixed Microalgae Species from Drain Water. Renew. Energy 2019, 131, 617-624. [CrossRef]

9. Kusumo, F.; Silitonga, A.S.; Masjuki, H.H.; Ong, H.C.; Siswantoro, J.; Mahlia, T.M.I. Optimization of Transesterification Process for Ceiba Pentandra Oil: A Comparative Study between Kernel-Based Extreme Learning Machine and Artificial Neural Networks. Energy 2017, 134, 24-34. [CrossRef]

10. Silitonga, A.; Shamsuddin, A.H.; Mahlia, T.; Milano, J.; Kusumo, F.; Siswantoro, J.; Dharma, S.; Sebayang, A.; Masjuki, H.; Ong, H.C. Biodiesel Synthesis from Ceiba Pentandra Oil by Microwave Irradiation-Assisted Transesterification: ELM Modeling and Optimization. Renew. Energy 2020, 146, 1278-1291. [CrossRef]

11. Silitonga, A.S.; Mahlia, T.M.I.; Kusumo, F.; Dharma, S.; Sebayang, A.H.; Sembiring, R.W.; Shamsuddin, A.H. Intensification of Reutealis Trisperma Biodiesel Production Using Infrared Radiation: Simulation, Optimisation and Validation. Renew. Energy 2019, 133, 520-527. [CrossRef]

12. Ho, S.-H.; Huang, S.-W.; Chen, C.-Y.; Hasunuma, T.; Kondo, A.; Chang, J.-S. Bioethanol Production Using Carbohydrate-Rich Microalgae Biomass as Feedstock. Bioresour. Technol. 2013, 135, 191-198. [CrossRef] [PubMed]

13. Sebayang, A.H.; Hasan, M.H.; Ong, H.C.; Dharma, S.; Bahar, A.H.; Silitonga, A.S.; Kusumo, F. Enzymatic Hydrolysis Using Ultrasound for Bioethanol Production from Durian (Durio zibethinus) Seeds as Potential Biofuel. Chem. Eng. Trans. 2017, 56, 553-558.

14. Silitonga, A.S.; Mahlia, T.M.I.; Ong, H.C.; Riayatsyah, T.M.I.; Kusumo, F.; Ibrahim, H.; Dharma, S.; Gumilang, D. A Comparative Study of Biodiesel Production Methods for Reutealis Trisperma Biodiesel. Energy Sources Part A-Recovery Util. Environ. Eff. 2017, 39, 2006-2014. [CrossRef]

15. Hossain, N.; Mahlia, T.M.I.; Saidur, R. Latest Development in Microalgae-Biofuel Production with Nano-Additives. Biotechnol. Biofuels 2019, 12, 125. [CrossRef] [PubMed]

16. Callegari, A.; Bolognesi, S.; Cecconet, D.; Capodaglio, A.G. Production Technologies, Current Role, and Future Prospects of Biofuels Feedstocks: A State-of-the-art Review. Crit. Rev. Environ. Sci. Technol. 2019, 1-53. [CrossRef]

17. Kusumo, F.; Silitonga, A.S.; Ong, H.C.; Masjuki, H.H.; Mahlia, T.M.I. A comparative study of ultrasound and infrared transesterification of Sterculia foetida oil for biodiesel production. Energy Sources Part A-Recovery Util. Environ. Effects 2017, 39, 13-1339. [CrossRef] 
18. Sebayang, A.H.; Masjuki, H.H.; Ong, H.C.; Dharma, S.; Silitonga, A.S.; Mahlia, T.M.I.; Aditiya, H.B. A Perspective on Bioethanol Production from Biomass as Alternative Fuel for Spark Ignition Engine. RSC Adv. 2016, 6, 14964-14992. [CrossRef]

19. Werpy, T.; Petersen, G.; Aden, A.; Bozell, J.; Holladay, J.; White, J.; Manheim, A.; Elliot, D.; Lasure, L.; Zones, S.; et al. Top Value Added Chemicals from Biomass Volume I: Results of Screening for Potential Candidates from Sugars and Synthesis Gas, Energy Efficiency and Renewable Energy; U.S.D.O., Ed.; National Renewable Energy Laboratory: Golden, CO, USA, 2004; pp. 1-76.

20. Faraco, V. (Ed.) Lignocellulose Conversion: Enzymatic and Microbial Tools for Bioethanol Production; Springer: Berlin, Germany, 2013; pp. 1-199.

21. Ingale, S.; Joshi, S.J.; Gupte, A. Production of Bioethanol Using Agricultural Waste: Banana Pseudo Stem. Braz. J. Microbiol. 2014, 45, 885-892. [CrossRef]

22. Abdullah, N.; Sulaiman, F.; Taib, R.M. Characterization of Banana (Musa Spp.) Plantation Wastes as a Potential Renewable Energy Source, AIP Conference Proceedings, 2013; AIP Publishing LLC.: Melville, LA, USA, 2013.

23. Velasquez, H.I.; Ruiz-Colorado, A.; De Oliveira, S., Jr. Ethanol Production from Banana Fruit and its Lignocellulosic Residues: Exergy and Renewability Analysis. Int. J. Thermodyn. 2009, 12, 155-162.

24. Horn, C.H.; du Preez, J.C.; Lategan, P.M. Protein Enrichment of Banana Plant Wastes by Yeast Cultivation. Biol. Wastes 1988, 24, 127-136. [CrossRef]

25. Oberoi, H.S.; Vadlani, P.V.; Saida, L.; Bansal, S.; Hughes, J.D. Ethanol Production from Banana Peels Using Statistically Optimized Simultaneous Saccharification and Fermentation Process. Waste Manag. 2011, 31, 1576-1584. [CrossRef] [PubMed]

26. Lin, C.-Y.; Peng, M.-T.; Tsai, Y.-C.; Tsai, S.-J.; Wu, T.-Y.; Chien, S.-Y.; Tsai, H.J. Bioconversion of Banana Pseudostem Fiber to Ethanol: Optimization of Acid Pretreatment Conditions and Fermentation Yeast Selection. Asian J. Agric. Food Sci. 2015, 3, 333-342.

27. Hossain, N.; Zaini, J.; Jalil, R.; Mahlia, T.M.I. The Efficacy of the Period of Saccharification on Oil Palm (Elaeis Guineensis) Trunk Sap Hydrolysis. Int. J. Technol. 2018, 9, 652-662. [CrossRef]

28. Hossain, N.; Haji Zaini, J.; Mahlia, T.M.I. A Review of Bioethanol Production from Plant-based Waste Biomass by Yeast Fermentation. Int. J. Technol. 2017, 8, 5-18. [CrossRef]

29. Hernández, L.; Kafarov, V. Use of Bioethanol for Sustainable Electrical Energy Production. Int. J. Hydrogen Energy 2009, 34, 7041-7050. [CrossRef]

30. Hossain, N.; Jalil, R. Analyses of Bio-Energy Properties from Malaysian Local Plants: Sentang and Sesendok. Asia Pac. J. Energy Environ. 2015, 2, 141-144. [CrossRef]

31. Hossain, N.; Jalil, R.; Mahlia, T.M.I.; Zaini, J. Calorific Value Analysis of Azadirachta Excelsa and Endospermum Malaccense as Potential Solid Fuels Feedstock. Int. J. Technol. 2017, 8, 634-643. [CrossRef]

32. Ong, H.C.; Masjuki, H.H.; Mahlia, T.M.I.; Silitonga, A.S.; Chong, W.T.; Leong, K.Y. Optimization of Biodiesel Production and Engine Performance from High Free Fatty Acid Calophyllum Inophyllum Oil in CI Diesel Engine. Energy Conver. Manag. 2014, 81, 30-40. [CrossRef]

33. Mohd Safaai, N.S.; Zainon Noor, Z.; Hashim, H.; Ujang, Z.; Talib, J. Projection of CO2 Emissions in Malaysia. Environ. Prog. Sustain. Energy 2011, 30, 658-665. [CrossRef]

34. John, B.H. Internal Combustion Engine Fundamentals, 2nd ed.; McGraw-Hill Education: New York, NY, USA, 2018.

35. Tartakovsky, L.; Sheintuch, M. Fuel Reforming in Internal Combustion Engines. Prog. Energy Combust. Sci. 2018, 67, 88-114. [CrossRef]

36. International Energy Agency. National Biofuel Policy of Malaysia (NBP 2006); International Energy Agency: Kuala Lumpur, Malaysia, 2006; Volume 2006.

37. Kusmiyati; Mustofa, A.; Jumarmi. Bioethanol Production From Banana Stem By Using Simultaneous Saccharification and Fermentation (SSF). IOP Conf. Ser. Mater. Sci. Eng. 2018, 358, 012004.

38. Laboratory, N.R.E. Getting Started Guide for Homer Legacy. In Homer: The Micropower Optimization Model; Version 2.68; US Department of Energy: Washington, DC, USA, 2011.

39. Das, B.K.; Hoque, N.; Mandal, S.; Kumar Pal, T.; Abu Raihan, M.A. Techno-Economic Feasibility of a Stand-Alone Hybrid Power Generation for Remote Area Application in Bangladesh. Energy 2017, 134, 775-788. [CrossRef]

40. Salinas, I. Engineering Evaluation; 25268, Raintree Partners; LLC: San Francisco, CA, USA, 2010; pp. 1-8. 
41. Shimizu, F.L.; Monteiro, P.Q.; Ghiraldi, P.H.C.; Melati, R.B.; Pagnocca, F.C.; Souza, W.d.; Sant'Anna, C.; Brienzo, M. Acid, Alkali and Peroxide Pretreatments Increase the Cellulose Accessibility and Glucose Yield of Banana Pseudostem. Ind. Crop. Prod. 2018, 115, 62-68. [CrossRef]

42. Trindade, S.C. Nanotech Biofuels and Fuel Additives, Biofuel's Engineering Process Technology. In Biofuel's Engineering Process Technology; Bernardes, M.A.D.S., Ed.; InTech: London, UK, 2011.

43. Hossain, N.; Jalil, R. Sugar and Bioethanol Production from Oil Palm Trunk (OPT). Asian Pac. J. Energy Environ. 2015, 2, 89-92. [CrossRef]

44. Varela, C.; Pizarro, F.; Agosin, E. Biomass Content Governs Fermentation Rate in Nitrogen-Deficient Wine Musts. Appl. Environ. Microbiol. 2004, 70, 3392. [CrossRef]

45. Velásquez-Arredondo, H.I.; Ruiz-Colorado, A.A.; De Oliveira, S., Jr. Ethanol Production Process from Banana Fruit and its Lignocellulosic Residues: Energy Analysis. Energy 2010, 35, 3081-3087. [CrossRef]

46. Rehman, S.; Nadeem, M.; Ahmad, F.; Mushtaq, Z. Biotechnological Production of Xylitol from Banana Peel and Its Impact on Physicochemical Properties of Rusks. J. Agric. Sci. Technol. 2013, 15, 747-756.

47. Kannan, B. Simultaneous Production of Xylitol and Ethanol from Different Hemicellulose Waste Substrates by Candida tropicalis Strain Ly15. J. Bioprocess. Biotech. 2016, 6, 2155-9821.

48. Damanik, N.; Ong, H.C.; Tong, C.W.; Mahlia, T.M.I.; Silitonga, A.S. A Review on the Engine Performance and Exhaust Emission Characteristics of Diesel Engines Fueled with Biodiesel Blends. Environ. Sci. Pollut. Res. Int. 2018, 25, 15307-15325. [CrossRef]

49. Hossain, N.; Zaini, J.; Indra Mahlia, T.M. Life Cycle Assessment, Energy Balance and Sensitivity Analysis of Bioethanol Production from Microalgae in a Tropical Country. Renew. Sustain. Energy Rev. 2019, 115, 109371. [CrossRef]

50. Ong, H.C.; Milano, J.; Silitonga, A.S.; Hassan, M.H.; Shamsuddin, A.H.; Wang, C.T.; Mahlia, T.M.I.; Siswantoro, J.; Kusumo, F.; Sutrisno, J. Biodiesel Production from Calophyllum Inophyllum-Ceiba Pentandra Oil Mixture: Optimization and Characterization. J. Clean. Prod. 2019, 219, 183-198. [CrossRef]

51. Matějovský, L.; Macák, J.; Pospíšil, M.; Baroš, P.; Staš, M.; Krausová, A. Study of Corrosion of Metallic Materials in Ethanol-Gasoline Blends: Application of Electrochemical Methods. Energy Fuels 2017, 31, 10880-10889. [CrossRef]

52. Ong, H.C.; Masjuki, H.H.; Mahlia, T.M.I.; Silitonga, A.S.; Chong, W.T.; Yusaf, T. Engine Performance and Emissions Using Jatropha Curcas, Ceiba Pentandra and Calophyllum Inophyllum Biodiesel in a CI Diesel Engine. Energy 2014, 69, 427-445. [CrossRef]

53. Silitonga, A.S.; Masjuki, H.H.; Ong, H.C.; Sebayang, A.H.; Dharma, S.; Kusumo, F.; Siswantoro, J.; Milano, J.; Daud, K.; Mahlia, T.M.I.; et al. Evaluation of the Engine Performance and Exhaust Emissions of Biodiesel-Bioethanol-Diesel Blends Using Kernel-Based Extreme Learning Machine. Energy 2018, 159, 1075-1087. [CrossRef]

54. Silitonga, A.S.; Masjuki, H.H.; Mahlia, T.M.I.; Ong, H.C.; Chong, W.T. Experimental Study on Performance and Exhaust Emissions of a Diesel Engine Fuelled with Ceiba Pentandra Biodiesel Blends. Energy Convers. Manag. 2013, 76, 828-836. [CrossRef]

55. Weekly Fuel Price Malaysia for RON95, RON97, and Diesel during 5-11 October 2019. Available online: https://malaysiafreebies.com/petrol-price-malaysia/ (accessed on 4 October 2019).

56. Ethanol Market and Pricing Data-20 February 2018. Available online: https://grains.org/ethanol_report/ ethanol-market-and-pricing-data-february-20-2018/ (accessed on 20 February 2018).

57. Hossain, N.; Mahlia, T.M.I.; Zaini, J.; Saidur, R. Techno-Economics and Sensitivity Analysis of Microalgae as Commercial Feedstock for Bioethanol Production. Environ. Prog. Sustain. Energy 2019, 38, 13157. [CrossRef]

58. Wahab, A.G. Global Agricultural Information Network Report: Malaysia Biofuels Annual; Office of Agricultural Affairs: Kuala Lumpur, Malaysia, 2017.

(C) 2019 by the authors. Licensee MDPI, Basel, Switzerland. This article is an open access article distributed under the terms and conditions of the Creative Commons Attribution (CC BY) license (http://creativecommons.org/licenses/by/4.0/). 